\title{
Increased degradation of type I collagen in patients with inflammatory bowel disease
}

\author{
J Silvennoinen, L Risteli, T Karttunen, J Risteli
}

\begin{abstract}
To assess the mechanisms of osteopenia in inflammatory bowel disease (IBD), the serum markers of bone formation (osteocalcin and carboxyterminal propeptide of type I procollagen (PICP)) and bone degradation (carboxyterminal telopeptide of type I collagen (ICTP)), the bone mineral density (BMD) of the lumbar spine and the proximal femur and calcium intake of 150 unselected IBD patients and 73 healthy controls were investigated. The patients had higher ICTP values (3.69 (SD 1.40) $\mu \mathrm{g} / 1)$ than the healthy controls $(3.25 \quad(1 \cdot 00) \mu g / l$,

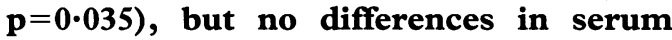
PICP and osteocalcin between these groups were detected. In the patients, the ICTP, PICP, and osteocalcin values did not have any significant correlation with BMD, but the patients with ICTP values above $3.6 \mu \mathrm{g} / \mathrm{l}$ had significantly lower $Z$ scores than those with lower ICTP. In the controls, however, a positive correlation between serum ICTP and BMD was found. The ulcerative colitis patients with total colitis had higher values of ICTP (3.96 $(1.58) \mu g / 1)$ than those with a left sided disease $(3.04(0.86) \mu g / l, p=0.009)$. The patients with a history of clinically active disease $(n=20)$ had higher ICTP $(4.58(1.55) \mu \mathrm{g} / 1)$ and osteocalcin (12.56 $(5.64) \mu g / 1)$ values than the patients $(n=130)$ with quiescent disease (ICTP 3.56 $(1 \cdot 33), p=0.002$, and osteocalcin 9.76 $(3 \cdot 62), p=0 \cdot 017)$. Increased serum osteocalcin, PICP, and ICTP concentrations and reduced $B M D Z$ scores were found in a subgroup of Crohn's disease patients with a history of an active disease $(n=11)$. Raised serum ICTP and normal values of osteocalcin and PICP in IBD patients show increased breakdown of type I collagen without a compensatory increase in its synthesis suggesting an increased rate of bone degradation as a probable mechanism for osteopenia in IBD. Raised ICTP values are related to reduced bone mineral densities.

(Gut 1996; 38: 223-228)
\end{abstract}

Keywords: bone mineral density, ICTP, inflammatory bowel disease, osteocalcin, PICP.

Reduced bone mineral densities (BMD) have been reported in patients with inflammatory bowel disease (IBD). ${ }^{1-3}$ Osteopenia in IBD patients seems to be associated with high lifetime corticosteroid doses, ${ }^{13}$ but other pathogenetic mechanisms, such as disease activity, a reduced absorption of calcium and vitamin $\mathrm{D}$, and a sex hormone deficiency, may also be involved. The diagnosis of osteopenia is based on BMD measurements, dual energy $x$ ray absorptiometry and computerised tomography being currently the most commonly used methods for measurements of the axial skeleton.

The main organic material of mineralised bone is type I collagen. In the recent years, it has become possible to measure simultaneously serum markers that reflect both the formation and degradation of this collagen type. The carboxyterminal propeptide of type I procollagen (PICP) is derived from type I procollagen, and a good correlation between the bone mineralisation rate and the serum PICP concentration has been reported. ${ }^{4}$ The cross linked carboxyterminal telopeptide of type I collagen (ICTP) is derived from the degradation of type I collagen molecules, which have been incorporated into collagen fibres. The cross link in the ICTP antigen is one of the mature, trivalent ones, being either hydroxylysylpyridinoline, lysylpyridinoline or pyrrole, whereas no degradation of immature type I collagen is detected. Thus, the serum ICTP concentration increases especially in clinical situations where abnormal bone destruction takes place (for example, multiple myeloma, ${ }^{5}$ osteolytic bone metastases, ${ }^{6}$ and rheumatoid arthritis $^{78}$ ). Serum ICTP correlates with the bone resorption rate in diseases with generally increased or decreased bone turnover, for example, hyperthyroidism, hypothyroidism or hyperparathyroidism. ${ }^{49}$ To investigate the pathogenesis of osteopenia in IBD, PICP, ICTP and a serum marker of osteoblastic activity, osteocalcin, were studied in 150 unselected IBD patients and 73 healthy controls.

\section{Methods}

Subjects

The patients were randomly taken from the IBD register of the Gastroenterology Unit at the Department of Internal Medicine, Oulu University Hospital, Oulu, Finland. They have been described in detail previously. ${ }^{3}$ The exclusion criteria for the patients were age under 19 or over 60 years, disease duration less than three years, IBD confined to the rectum only, and pregnancy. As the serum ICTP concentration increases in renal failure, two patients (one man and one woman) with Crohn's disease and nephritis (and high serum ICTP and PICP concentrations) were excluded from this study. The diagnosis, the 
extent, and the type of the IBD were determined using uniform clinical ${ }^{10}$ and pathological ${ }^{11}$ criteria. $^{3}$ All the histological samples were evaluated by one pathologist (TK). The activity of the inflammation was histologically evaluated according to the criteria described by Rutegard et $a l^{12}$ and the extent of active inflammation was determined. Sixty seven patients had ulcerative colitis, 76 had Crohn's disease, and seven had indeterminate colitis. The mean time since the diagnosis of IBD was $11.5(6.0)$ (range 3-32) years. The 150 IBD patients were compared with 73 healthy controls with a similar age and sex distribution. Both the patients and the controls came from the same area around Oulu in northern Finland. The mean age of the male patients was $39.6(8.5)$ years and that of male controls was $40.9(9.1)$ years (NS). The ages of the women were also similar (patients 40.3 (10.1) years and controls $40 \cdot 7(9 \cdot 5)$ years). Fourteen $(19.7 \%)$ of 71 female patients and seven $(18.4 \%)$ of 38 female controls were postmenopausal (NS).

\section{Biochemical measurements}

The blood samples were taken in the morning after an overnight fast. Routine laboratory methods were used to measure serum calcium and phosphate. Serum alkaline phosphatase was measured according to the Scandinavian recommendations. ${ }^{13}$ Serum intact parathyroid hormone was determined with a two site immunoradiometric assay (Nichols Institute, San Juan Capistrano, CA, USA). ICTP was measured in duplicate $100 \mu \mathrm{l}$ aliquots of serum using a recently developed equilibrium radioimmunoassay (Orion Diagnostica, Oulunsalo, Finland). ${ }^{14}$ The standard and tracer antigens of the assay are cross linked carboxyterminal telopeptide parts of type I collagen liberated by digestion with bacterial collagenase from decalcified human femoral bone. The intra-assay variation of the ICTP assay is around $6 \%$ and the interassay variation less than $8 \% .^{14}$ Serum intact osteocalcin was assayed with a competitive radioimmunoassay using the coated tube technique (Oscatest by Henning Berlin, Berlin, Germany). PICP was measured with a radioimmunoassay (Orion Diagnostica, Oulunsalo, Finland), and the reference ranges previously published by Melkko et al ${ }^{15}$ were applied.

\section{Bone density measurements}

The BMD was measured from the spine and the left proximal femur using dual energy $x$ ray absorptiometry (Lunar DPX, Lunar Radiation Corporation, Madison, WI, USA). For each patient, the values of BMD were also calculated as the deviation from the population mean, expressed as standard deviations ( $Z$ score), which was based on the previously published Finnish normal values corrected for sex and age. ${ }^{1617}$ The precision of the method (coefficient of variation) was $1 \cdot 38 \%$ for $\mathrm{BMD}$ in the spine, $1.61 \%$ for the femoral neck, $3.60 \%$ for Ward's triangle, and $1.59 \%$ for the trochanter. The technique used has already been presented in detail. ${ }^{3}$

\section{Calcium intake}

Dietary calcium intake was estimated using a semiquantitative food frequency questionnaire comprising 48 food items. The same method has been used in a similar study. ${ }^{18}$ The subjects who did not use milk products or other dairy products containing considerable amounts of lactose were classified as having a low lactose diet. To minimise seasonal variation, all the interviews and BMD measurements were performed and blood samples taken in April and May 1993.

\section{Statistical analysis}

The data are presented as means (SD). Student's unpaired $t$ test was used when appropriate. When the variances were unequal or the distribution was not normal, the MannWhitney $U$ test was used. A comparison of incidences was performed by using $\chi^{2}$ statistics or Fisher's exact test. Pearson's correlation coefficients were calculated for the continuous variables. Two tailed values for significance were used in all the statistical tests, and significance was defined as $\mathrm{p}<0.05$. The analyses were made with the Statistical Package for Social Sciences (SPSS). The statistical software Confidence Interval Analysis (CIA), version 1.0 , was used to calculate the $95 \%$ confidence intervals $(\mathrm{CI})$.

\section{Ethical considerations}

The study was approved by the ethical committee of the Oulu University Hospital and informed consent was obtained from all the patients and controls before the investigation.

\section{Results}

The patients had higher ICTP values than the healthy controls, but no differences in serum PICP and osteocalcin between these groups were detected (Table I). No sex related difference in the ICTP values was found, but the PICP values were lower in women than in men both in the patients (men 137 (43) $\mu \mathrm{g} / \mathrm{l}$ and women 119 (35) $\mu \mathrm{g} / \mathrm{l}, \mathrm{p}=0.012)$ and in the controls (men $142(72) \mu g / l$ and women 115 (34) $\mu g / l, p=0.060)$. In the IBD patients, serum osteocalcin was higher in men $(10.8$ (4.0) $\mu \mathrm{g} / \mathrm{l})$ than in women $(9.5(4.0) \mu \mathrm{g} / \mathrm{l}$, $\mathrm{p}=0.004)$, whereas no corresponding difference was found in the controls. Table II shows the correlations of PICP, ICTP, and osteocalcin with age, the $Z$ scores of $B M D$ and some laboratory variables in IBD patients. In the controls, ICTP correlated with age $(r=-0.363, \mathrm{CI}-0.547$ to $-0.145, \mathrm{p}=0.002)$ and with PICP $(r=0.245$, CI 0.016 to 0.450 , $\mathrm{p}=0.037$ ), but not with the serum calcium, phosphate or parathyroid hormone values, and osteocalcin correlated with ICTP $(r=0.330$, CI 0.018 to $0.521, \mathrm{p}=0.004)$, PICP $(r=0.432$, CI 0.224 to $0.602, \mathrm{p}<0.001)$, and serum 
TABLE I Serum markers of bone formation and breakdown in 150 IBD patients and 73 controls. The values are means (SD) and range

\begin{tabular}{llcl}
\hline & Patients & Controls & Significance $^{\star}$ \\
\hline Number (men/women) & $150(79 / 71)$ & $73(35 / 38)$ & \\
Osteocalcin $(\mu \mathrm{g} / \mathrm{l})$ & $10 \cdot 1(4 \cdot 0)(3 \cdot 7-29 \cdot 8)$ & $9 \cdot 3(3 \cdot 1)(4 \cdot 2-17 \cdot 9)$ & $\mathrm{NS}$ \\
PICP $(\mu \mathrm{g} / 1)$ & $128(40)(64-308)$ & $128(57)(53-476)$ & $\mathrm{NS}$ \\
ICTP $(\mu \mathrm{g} / \mathrm{l})$ & $3 \cdot 69(1.40)(1 \cdot 6-9 \cdot 2)$ & $3 \cdot 25(1.00)(1 \cdot 7-6 \cdot 3)$ & $\mathrm{p}=0.035$ \\
\hline
\end{tabular}

^Mann-Whitney U test, NS, if $\mathrm{p}>0.05$.

alkaline phosphatase $(r=0.336$, CI 0.115 to $0 \cdot 525, \mathrm{p}=0 \cdot 004)$.

In the patients, the ICTP, PICP, and osteocalcin values did not correlate with $\mathrm{BMD}$ or its $\mathrm{Z}$ score values at any of the measurement sites (Table II, Fig 1). In the controls, serum ICTP had positive correlations with the $\mathrm{Z}$ scores in the femoral neck $(r=0.325$, CI 0.103 to 0.516 , $\mathrm{p}=0.005)$ and in Ward's triangle $(r=0.298, C I$ 0.073 to $0.494, p=0.011$ ), whereas no significant correlations were found between PICP and the $\mathrm{Z}$ scores. The ability of the serum ICTP concentration to detect low BMD was assessed by calculating the $\mathrm{Z}$ scores of $\mathrm{BMD}$ for the two groups formed by increasing (interval $0 \cdot 1 \mu \mathrm{g} / \mathrm{l}$ ) cut off concentrations of ICTP. A cut off point of $3.6 \mu \mathrm{g} / \mathrm{l}$ was found to discriminate most effectively between the patients with low and higher BMD values. Within the patient group, the subjects with high ICTP values showed a uniform trend towards lower $\mathrm{BMD}$ and $\mathrm{Z}$ score values, whereas within the control group the trend was the opposite (Table III).

Neither the patients nor the controls with increased osteocalcin (men $>12 \mu \mathrm{g} / \mathrm{l}$, women $>10 \mu \mathrm{g} / \mathrm{l}$ ) or increased serum PICP (men $>202 \mu \mathrm{g} / \mathrm{l}$, women $>170 \mu \mathrm{g} / \mathrm{l}$ ) had significantly different BMD or $\mathrm{Z}$ score values at any of the measurement sites when compared with the subjects who had normal serum osteocalcin and PICP. No association between serum alkaline phosphatase and BMD was found. The total cumulative lifetime corticosteroid doses were slightly, but not significantly, lower in the patients with serum ICTP $\leqslant 3.6 \mu \mathrm{g} / 1(4 \cdot 0(5 \cdot 9) \mathrm{g}$ of prednisolone/prednisone) than in the patients with ICTP $>3.6 \mu \mathrm{g} / 1(6.0(8.1) \mathrm{g}$, $\mathrm{p}=0 \cdot 107)$. The serum ICTP, PICP, and osteocalcin values did not correlate with the lifetime corticosteroid doses. Thirteen patients were taking oral corticosteroids (mean daily dose 11.5 (SD $10 \cdot 3$, range $2.5-10$ ) $\mathrm{mg}$ of prednisolone/prednisone) at the time of the study. Their ICTP (4.07 (1.92) $\mu \mathrm{g} / \mathrm{l})$ PICP (140 (57) $\mu \mathrm{g} / \mathrm{l})$ and osteocalcin $(11 \cdot 0(6 \cdot 4) \mu \mathrm{g} / \mathrm{l})$ values

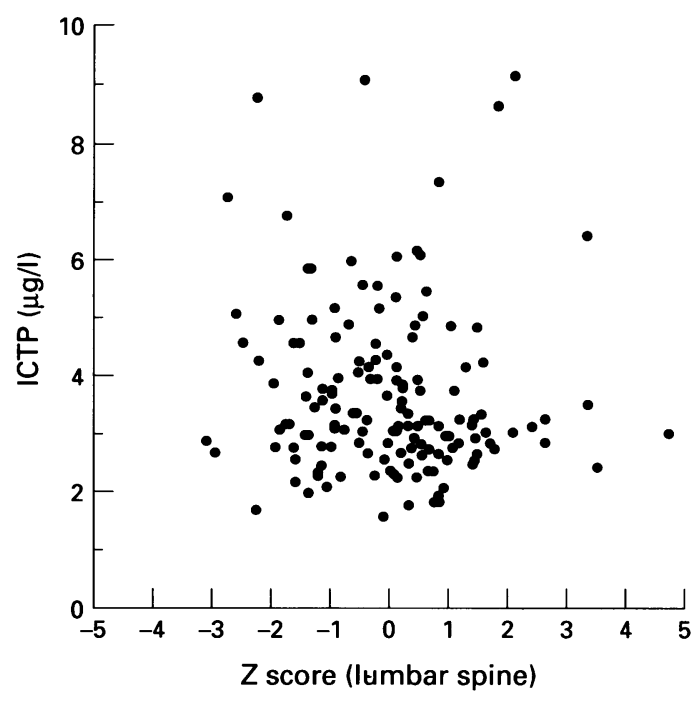

Figure 1: Scatter plot of the cross linked ICTP $(\mu g /)$ and the $Z$ scores of bone mineral density in the lumbar spine of the 150 patients with inflammatory bowel disease.

were not significantly different from the other IBD patients.

No differences were detected in the serum ICTP, PICP or osteocalcin concentrations between the patients with ulcerative colitis $(n=67)$ and Crohn's disease $(n=76)$. The patients who, during the course of their disease, had had relapses requiring changes in treatment more often than twice a year or continuously had a clinically active disease $(n=20)$ had higher ICTP $(4.58(1.55) \mu \mathrm{g} / \mathrm{l})$ and osteocalcin $(12.6(5.6) \mu \mathrm{g} / \mathrm{l})$ values than the patients $(n=130)$ with more quiescent disease (ICTP $3.56(1.33) \mu \mathrm{g} / \mathrm{l}, \mathrm{p}=0.002$ and osteocalcin 9.8 $(3.6) \mu \mathrm{g} / \mathrm{l}, \mathrm{p}=0.017)$. No significant difference in serum PICP between these two groups was detected, but raised serum osteocalcin, PICP, and ICTP and reduced BMD Z scores were found in Crohn's disease patients with a history of active disease. They also had higher serum PICP than the patients with a history of active ulcerative colitis (Table IV). The patients with diarrhoea or blood in stools on a daily basis or with generalised symptoms (for example, fever) at the time of the clinical examination $(n=24)$ did not have PICP, ICTP or osteocalcin values different from those of the patients with milder or no symptoms at that time $(n=126)$. These results were also similar if the patients with ulcerative colitis and Crohn's disease were analysed separately.

The ulcerative colitis patients with total colitis in the histological samples had higher

TABLE II Pearson's correlation coefficients ( $p$ values in parentheses) between the markers of bone formation and degradation and age, $Z$ scores of the bone mineral density, and other laboratory variables in 150 patients with inflammatory bowel disease

\begin{tabular}{|c|c|c|c|c|c|c|c|c|c|c|}
\hline & Age & $\begin{array}{l}Z \text { score } \\
\text { lumbar spine }\end{array}$ & $\begin{array}{l}Z \text { score } \\
\text { femoral neck }\end{array}$ & $\begin{array}{l}\text { Parathyroid } \\
\text { hormone }\end{array}$ & $\begin{array}{l}\text { 25-Hydroxy } \\
\text { vitamin } D\end{array}$ & $\begin{array}{l}\text { Serum } \\
\text { phosphate }\end{array}$ & $\begin{array}{l}\text { Alkaline } \\
\text { phosphatase }\end{array}$ & $\begin{array}{l}\text { Serum } \\
\text { calcium }\end{array}$ & Osteocalcin & $I C T P$ \\
\hline \multicolumn{11}{|l|}{ PICP } \\
\hline$r$ & $-0.191(p=0.020)$ & $-0.120(p=0.145)$ & $-0.105(p=0.205)$ & $0.045(p=0.586)$ & $0.000(p=0.998)$ & $0.203(p=0.013)$ & $0.250(p=0.002)$ & $-0.062(p=0.453)$ & $0.511(\mathrm{p}<0.001)$ & $0.299(\mathrm{p}<0.001)$ \\
\hline $\mathrm{CI}^{\star}$ & -0.341 to -0.037 & -0.275 to 0.041 & -0.261 to 0.056 & -0.116 to 0.204 & -0.160 to 0.160 & 0.044 to 0.352 & 0.094 to 0.394 & -0.220 to 0.099 & 0.382 to 0.620 & 0.146 to 0.438 \\
\hline \multicolumn{11}{|l|}{ ICTP } \\
\hline$r$ & $-0.340(p<0.001)$ & $-0.109(p=0 \cdot 185)$ & $-0.109(p=0.188)$ & $0.029(p=0.724)$ & $0.051(p=0.540)$ & $0.277(p=0.001)$ & $1.169(p=0.040)$ & $-0.060(p=0.466)$ & $0.477(\mathrm{p}<0.001)$ & \\
\hline $\mathrm{CI}^{\star}$ & -0.473 to 0.190 & -0.265 to 0.052 & -0.265 to 0.052 & -0.132 to 0.188 & -0.110 to 0.210 & 0.122 to 0.419 & 0.009 to 0.321 & -0.218 to 0.101 & 0.343 to 0.592 & \\
\hline \multicolumn{11}{|c|}{ Osteocalcin } \\
\hline$r$ & $-0.156(p=0.057)$ & $-0.098(p=0.234)$ & $-0.142(p=0.085)$ & $0.105(p=0.202)$ & $0.104(p=0.208)$ & $0.295(p<0.001)$ & $0.193(p=0.018)$ & $0.153(p=0.063)$ & & \\
\hline $\mathrm{CI}^{\star}$ & -0.309 to 0.004 & -0.254 to 0.063 & -0.296 to 0.019 & -0.056 to 0.261 & -0.057 to 0.260 & 0.141 to 0.435 & 0.034 to 0.343 & -0.007 to 0.306 & & \\
\hline
\end{tabular}

$\star 95 \%$ confidence intervals for the correlation coefficient. 


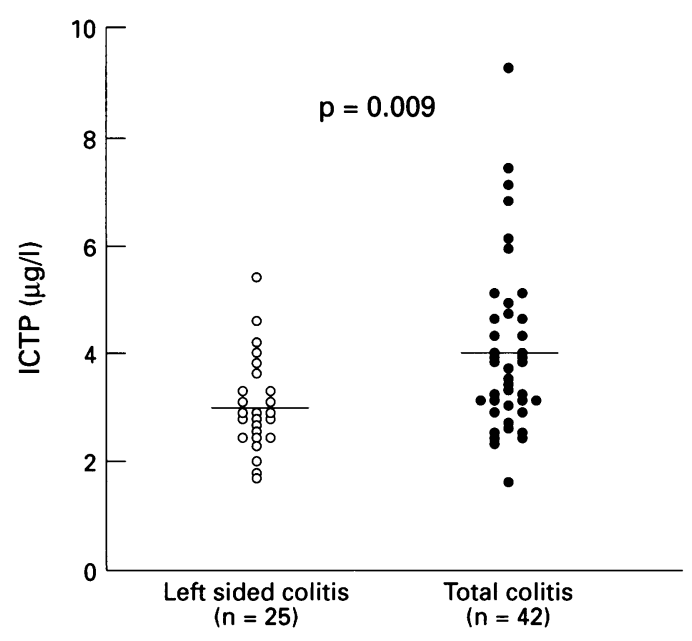

Figure 2: Concentration of the cross linked ICTP $(\mu g / l)$ in the serum of 67 ulcerative colitis patients with either left sided or total colitis in histological samples.

circulating concentrations of ICTP than the ulcerative colitis patients with a left sided disease (Fig 1). Ten of $42(23.8 \%)$ ulcerative colitis patients with total colitis and one of 25 $(4.0 \%)$ with left sided colitis had ICTP concentrations above the upper limit of the reference interval, $4.6 \mu \mathrm{g} / \mathrm{l}(\mathrm{p}=0.043$, Fisher's two tailed exact test). In the ulcerative colitis patients with total colitis, the PICP values were slightly, but not significantly, increased (135 (39) $\mu \mathrm{g} / 1$ and 118 (27) $\mu \mathrm{g} / \mathrm{l}, \mathrm{NS}$ ). The exclusion of the patients with total colitis from the analysis, however, had no significant effect on the correlations of the serum PICP, ICTP, and osteocalcin concentrations with the BMD Z scores. The Crohn's disease patients with ileitis $(n=50)$ had serum PICP, ICTP, and osteocalcin concentrations similar to those of the other Crohn's disease patients $(n=26)$. Similarly, the extent of the Crohn's disease in the colon had no effect on these parameters.

The serum osteocalcin, PICP or ICTP of the IBD patients with previous colectomy $(n=12)$ were not different from those of the other patients $(n=138)$. The serum ICTP concentration correlated with the histological activity of the inflammation in the biopsy specimens taken at the latest colonoscopy $(r=0.203$, CI 0.044 to $0.352, \mathrm{p}=0.028)$ as well as with the histological activity in the specimens taken when the inflammation was seen to be most extensive $(r=0 \cdot 265$, CI $0 \cdot 109$ to $0 \cdot 408, p=0 \cdot 004)$. No correlation was found between serum PICP or osteocalcin and the activity of inflammation.

Serum PICP, ICTP, and osteocalcin did not correlate with the dietary calcium intake either in the patient or in the control group. Serum PICP was slightly, but not significantly, lower in the patients with a low lactose diet (124 (45) $\mu \mathrm{g} / \mathrm{l}, \mathrm{n}=70$ ) than in those with a normal $\operatorname{diet}(132(36) \mu \mathrm{g} / \mathrm{l}, \mathrm{n}=80, \mathrm{p}=0.058)$. Serum osteocalcin was lower in the controls with a low lactose diet $(9.6(3 \cdot 1) \mu \mathrm{g} / \mathrm{l}, \mathrm{n}=8)$ than in the controls with a normal diet $(7 \cdot 0(1 \cdot 6) \mu \mathrm{g} / \mathrm{l}$, $\mathrm{n}=65, \mathrm{p}=0.006$ ). No other associations were found between the low lactose diet and osteocalcin, PICP or ICTP. Neither the patients, nor the controls with a daily calcium intake below $600 \mathrm{mg}(\mathrm{n}=18(12 \%)$ in the patient and $\mathrm{n}=3(4 \cdot 1 \%)$ in the control group) had different ICTP values compared with the subjects receiving more calcium in the corresponding group. There were no differences in serum PICP or osteocalcin between those who had earlier sustained fractures (none had a history of fragility fracture) and those who had not; this was true of both the IBD patients and the controls. The IBD patients with a history of previous fractures $(n=46)$, however, had lower current ICTP values $(3.41(1.40) \mu \mathrm{g} / \mathrm{l})$ than those with no fractures $(3.82(1.38) \mu \mathrm{g} / \mathrm{l}$, $p=0.045)$. The ages of the patients in these two groups were not statistically different $(40.9$ $(8 \cdot 8)$ and $39.5(9.5)$ years, respectively).

\section{Discussion}

In this cross sectional study, unselected adult IBD patients had significantly increased serum ICTP concentrations when compared with healthy controls, whereas no differences were found in markers of bone formation PICP, and osteocalcin. The patients with serum ICTP above $3.6 \mu \mathrm{g} / \mathrm{l}$ had higher $\mathrm{BMD}$ in the spine and in the proximal femur than the patients with lower serum ICTP values. As would be expected because of the coupling of the bone remodelling, we found positive correlations with serum ICTP and markers of bone formation, alkaline phosphatase, osteocalcin, and PICP. The findings are similar to Eriksen et al. ${ }^{9}$ Serum total alkaline phosphatase may not be a reliable marker of bone metabolism in IBD patients because of the frequent liver

TABLE III Bone mineral density (BMD $\mathrm{g} / \mathrm{cm}^{2}$ ) and $Z$ scores (from data by Kröger et al 1992) in IBD patients and controls with $\leqslant 3 \cdot 6 \mu \mathrm{g} / \mathrm{l}$ and $>3 \cdot 6$ $\mu \mathrm{g} / \mathrm{v}$ values of ICTP. The values are means ( $S D$ or range (for $Z$ scores))

\begin{tabular}{|c|c|c|c|c|c|c|}
\hline & \multicolumn{3}{|l|}{ Patients } & \multicolumn{3}{|l|}{ Controls } \\
\hline & $I C T P \leqslant 3 \cdot 6$ & $I C T P>3 \cdot 6$ & Significance ${ }^{\star}$ & $I C T P \leqslant 3 \cdot 6$ & $I C T P>3.6$ & Significance ${ }^{\star}$ \\
\hline $\begin{array}{l}\text { Number (men/women) } \\
\text { ICTP }(\mu \mathrm{g} / \mathrm{l}) \text { (range) } \\
\text { BMD }\end{array}$ & $\begin{array}{l}90(49 / 41) \\
2 \cdot 8(0.5)(1.6 \text { to } 3 \cdot 6)\end{array}$ & $\begin{array}{l}60(30 / 30) \\
5 \cdot 0(1 \cdot 3)(3 \cdot 7 \text { to } 9 \cdot 2)\end{array}$ & & $\begin{array}{l}53(28 / 25) \\
2.8(0.5)(1.7 \text { to } 3.6)\end{array}$ & $\begin{array}{l}20(7 / 13) \\
4.6(0.7)(3.8 \text { to } 6.3)\end{array}$ & \\
\hline $\begin{array}{l}\text { Lumbar spine } \\
\text { Femoral neck } \\
\text { Ward's triangle } \\
\text { Trochanter }\end{array}$ & $\begin{array}{l}1 \cdot 199(0 \cdot 184) \\
0.960(0 \cdot 148) \\
0 \cdot 857(0 \cdot 167) \\
0 \cdot 864(0 \cdot 137)\end{array}$ & $\begin{array}{l}1 \cdot 146(0 \cdot 153) \\
0.930(0 \cdot 137) \\
0 \cdot 838(0 \cdot 151) \\
0.801(0 \cdot 146)\end{array}$ & $\begin{array}{l}\text { NS } \\
\text { NS } \\
\mathrm{p}=0.007\end{array}$ & $\begin{array}{l}1.210(0 \cdot 149) \\
0.979(0 \cdot 129) \\
0 \cdot 863(0 \cdot 159) \\
0 \cdot 874(0.116)\end{array}$ & $\begin{array}{l}1.275(0 \cdot 168) \\
1.060(0.150) \\
0.959(0.155) \\
0.925(0.148)\end{array}$ & $\begin{array}{l}\text { NS } \\
p=0.024 \\
p=0.023 \\
\text { NS }\end{array}$ \\
\hline $\begin{array}{l}\text { Z score } \\
\text { Lumbar spine } \\
\text { Femoral neck } \\
\text { Ward's triangle } \\
\text { Trochanter }\end{array}$ & $\begin{array}{r}0.20(-3.11 \text { to } 4.74) \\
-0.22(-3.55 \text { to } 3.73) \\
0.02(-2.76 \text { to } 4.64) \\
0.02(-2.27 \text { to } 2 \cdot 84)\end{array}$ & $\begin{array}{l}-0.35(-2.77 \text { to } 3.35) \\
-0.58(-4.17 \text { to } 1.55) \\
-0.37(-3.51 \text { to } 1.98) \\
-0.49(-3.99 \text { to } 1.87)\end{array}$ & $\begin{array}{l}p=0.013 \\
N S \\
p=0.046 \\
p=0.011\end{array}$ & $\begin{array}{r}0.29(-2.29 \text { to } 2.57) \\
-0.06(-2.03 \text { to } 3.30) \\
0.04(-1.98 \text { to } 3.71) \\
0.15(-1.66 \text { to } 3.09)\end{array}$ & $\begin{array}{l}0.70(-2.00 \text { to } 2.94) \\
0.60(-1.55 \text { to } 2.71) \\
0.59(-0.97 \text { to } 2.12) \\
0.67(-1.07 \text { to } 2.99)\end{array}$ & $\begin{array}{l}\text { NS } \\
p=0.022 \\
N S \\
p=0.048\end{array}$ \\
\hline
\end{tabular}

Student's unpaired $t$ test (NS, if $\mathrm{p}>0 \cdot 05)$. 
TABLE IV Serum osteocalcin, PICP, ICTP, and Z scores of bone mineral density of the patients with ulcerative colitis and Crohn's disease in relation to the past clinical activity of the disease. The values are means (SD or range (for $Z$ scores))

\begin{tabular}{|c|c|c|c|c|c|c|}
\hline & \multicolumn{3}{|l|}{ Crohn's disease } & \multicolumn{3}{|l|}{ Ulcerative colitis } \\
\hline & Active $(n=11) t$ & Others $(n=65)$ & Significance ${ }^{\star}$ & Active $(n=9)+$ & Others $(n=58)$ & Significance ${ }^{\star}$ \\
\hline $\begin{array}{l}\text { Osteocalcin }(\mu \mathrm{g} / \mathrm{l}) \\
\text { PICP }(\mu \mathrm{g} / \mathrm{l}) \\
\text { ICTP }(\mu \mathrm{g} / \mathrm{l}) \\
Z \text { score }\end{array}$ & $\begin{array}{c}13.3(6.9) \\
168.5(66.4) \ddagger \\
4.8(1.5)\end{array}$ & $\begin{array}{c}9.5(3 \cdot 5) \\
123.6(37 \cdot 0) \\
3.6(1 \cdot 3)\end{array}$ & $\begin{array}{l}0.035 \\
0.012 \\
0.004\end{array}$ & $\begin{array}{c}11 \cdot 6(3 \cdot 8) \\
109 \cdot 9(28 \cdot 5) \ddagger \\
4 \cdot 3(1 \cdot 7)\end{array}$ & $\begin{array}{c}9 \cdot 9(3 \cdot 6) \\
130 \cdot 3(35 \cdot 2) \\
3.5(1 \cdot 4)\end{array}$ & $\begin{array}{l}\text { NS } \\
\text { NS } \\
\text { NS }\end{array}$ \\
\hline $\begin{array}{l}\text { Lumbar spine } \\
\text { Femoral neck }\end{array}$ & $\begin{array}{l}-0.88(-2 \cdot 24 \text { to } 1 \cdot 10) \\
-1 \cdot 47(-2 \cdot 13 \text { to }-0 \cdot 25)\end{array}$ & $\begin{array}{l}-0.05(-2.94 \text { to } 3.38) \\
-0.25(-2.31 \text { to } 2 \cdot 01)\end{array}$ & $\begin{array}{l}0.035 \\
0.0005\end{array}$ & $\begin{array}{l}-0.24(-1.96 \text { to } 2.65) \\
-0.52(-2.22 \text { to } 2.90)\end{array}$ & $\begin{array}{r}0.08(-3.11 \text { to } 4.74) \\
-0.36(-4.17 \text { to } 3.73)\end{array}$ & $\begin{array}{l}\text { NS } \\
\text { NS }\end{array}$ \\
\hline
\end{tabular}

${ }^{\star}$ Mann-Whitney $U$ test, NS, if $p>0 \cdot 05$. TThe patients with a disease history with relapses requiring changes in treatment on average more often than twice a year or a continuously active disease. $\neq p=0.017$

involvement in IBD. This is suggested by our results, which showed better correlation with alkaline phosphatase and another marker of the osteoblast activity, osteocalcin, among the healthy controls than among IBD patients.

Pietschmann et al reported increased serum osteocalcin concentrations in 10 patients with lactase deficiency and a very low calcium intake. ${ }^{19}$ We found no such differences related to either a low lactose diet or a low calcium intake. In this study, we were also unable to show any differences in PICP or ICTP. This may show that the Finnish patients with a low lactose diet probably do not have rates of bone formation or degradation different from those of normal controls. The calcium intakes found in our study, even in the subjects with a low lactose diet, were clearly higher than those in the study by Pietschmann from Austria, and this may explain some of the difference.

The main component of the organic matrix of the bone is type I collagen, which accounts for about $90 \%$ of the total organic material in bone. PICP is a protein derived from type I procollagen, which is formed in a 1:1 stoichiometric ratio to type I collagen molecules. ICTP is derived from the breakdown of type I collagen molecules that have participated in collagen fibres. Serum PICP measurements have been validated as a marker of bone formation and serum ICTP as a marker of bone resorption both in histomorphometrical ${ }^{9}$ and in calcium kinetic studies. ${ }^{4}$ The tissue concentration of PICP seems to be a good indicator of local type I collagen synthesis. ${ }^{2021}$ As no gradient in the PICP concentration between lymph and blood has been found, ${ }^{22}$ it seems that the concentration of circulating PICP is not normally determined by the soft tissues drained by lymph.

We are not aware of any completely reported studies where the serum PICP and ICTP concentrations would have been assessed in IBD patients. Preliminary data published in abstract form reported increased ICTP, but normal or low normal PICP values in patients with active Crohn's disease. ${ }^{23}$ In another abstract, osteocalcin and PICP were normal in patients with IBD, but bone resorption markers in the urine (hydroxylysylpyridinoline and lysylpyridinoline) were increased. ${ }^{24}$ According to our data, the IBD patients with higher serum ICTP have reduced BMD in a cross sectional study. In the controls with normal and balanced bone turnover the higher bone mass may result in higher serum concentrations of ICTP and thus explain the positive correlation between BMD and ICTP (Table III). Further studies are needed to establish the value of the ICTP test in discriminating the IBD patients with an increased risk for the development of osteoporosis and fractures.

In addition to disease activity, impaired nutritional state, sex hormone deficiency and malabsorption of calcium and vitamin $\mathrm{D}$, and treatment with glucocorticosteroids ${ }^{3}$ are possible pathogenetic factors in IBD associated osteopenia. In a study by Oikarinen et al, ${ }^{25}$ systemically given glucocorticoids decreased the concentration of PICP in serum. In our study, the small amount of current corticosteroid users did not have different serum osteocalcin, PICP or ICTP concentrations when compared with other IBD patients and no association was found between the total lifetime corticosteroid dose and these laboratory parameters. It is thus possible that the increased type I collagen degradation in IBD reflects a direct effect of disease activity on bone metabolism.

Increased serum ICTP concentrations are commonly seen in rheumatoid arthritis and associated with the aggressivity of the disease. ${ }^{78}$ Although periarticular and general osteoporosis are features of the disease, ICTP can, in principle, also be derived from type I collagen destruction taking place in soft tissues, which also contain type I collagen having trivalent cross links. This could partly explain our findings on the increased serum ICTP in association with total colitis and histologically active colitis. The ulcerative colitis patients with total colitis also had slightly raised serum PICP concentrations suggesting an increased type I collagen synthesis. In a previous study, we were unable to show any association with $\mathrm{BMD}$ or the extent or type of IBD. ${ }^{3}$ If considerable amounts of ICTP were derived from the soft tissues in all IBD patients, increased PICP values as an indicator of increased synthesis of type I collagen resulting from fibrosis and inflammation would be expected. This was, however, found only in a small subgroup of patients with a disease history of active Crohn's disease (Table IV). Still, the soft connective tissue involvement in IBD may reduce the value of serum PICP and ICTP as markers of bone matrix metabolism. It is also possible that the mechanisms of osteopenia vary according to the type of the IBD and the disease activity. The soft tissue collagen metabolism could be further investigated in patients with IBD by assessing the metabolism of type III collagen, for example, the 
aminoterminal propeptide of type III procollagen, a marker of type III collagen synthesis. In addition, further studies on the metabolism of type I collagen to assess possible soft tissue involvement with respect to the disease activity and the type of IBD are required.

We conclude that the patients with IBD have increased serum ICTP and normal concentrations of osteocalcin and PICP, suggesting that an increased rate of bone collagen degradation may be the cause for osteopenia in these patients. In active Crohn's disease all of these markers of bone metabolism are increased. In the patients with ulcerative colitis, the greater extent of the disease and the histological activity are associated with increased serum ICTP. As the IBD patients with serum ICTP above $3.6 \mu \mathrm{g} / 1$ had reduced BMD, the ICTP test may be useful in discriminating patients at risk for developing osteopenia.

This work was supported by grants from the Finnish Foundation for Gastroenterological Research, the Medical Research Council of the Academy of Finland, and the Oulu University Hospital.

1 Compston JE, Judd D, Crawley EO, Evans WD, Evans C, Church HA, et al. Osteoporosis in patients with inflammatory bowel disease. Gut 1987; 28: 410-5.

2 Pigot F, Roux C, Chaussade S, Hardelin D, Pelleter O, Du Poy Montbrun T, et al. Low bone mineral density in patients with inflammatory bowel disease. Dig Dis $\mathrm{Sc}$ 1992; 9: 1396-403.

3 Silvennoinen J, Karttunen T, Niemelä S, Manelius J, Lehtola J. A controlled study of bone mineral density in patients with inflammatory bowel disease. Gut 1995; 37: patien.

4 Charles P, Mosekilde L, Risteli L, Risteli J, Eriksen EF. Assessment of bone remodeling using biochemical indicators of type I collagen synthesis and degradation: relation tors of type I collagen synthesis and degradation:

5 Elomaa I, Virkkunen P, Risteli I, Risteli J. Serum concentration of the cross-linked carboxyterminal telopeptide of type I collagen (ICTP) is a useful prognostic indicator in multiple myeloma. Br f Cancer 1992; 66: 337-41.

6 Kylmälä T, Tammela T, Risteli L, Risteli J, Taube T, Elomaa I. Evaluation of the effect of oral clodronate on skeletal metastases with type I collagen metabolites. A controlled trial of the Finnish prostate cancer group. Eur $\mathcal{F}$ Cancer 1993; 29A: 821-5.

7 Hakala M, Risteli L, Manelius J, Nieminen P, Risteli J. Increased type I collagen degradation correlates with disease severity in rheumatoid arthritis. Ann Rheum Dis 1993; 52: 866-9.

8 Kotaniemi A, Isomäki H, Hakala M, Risteli L, Risteli J. Increased type I collagen degradation in early rheumatoid arthritis. $\mathcal{f}$ Rheumatol 1994; 21 : 1593-6.
9 Eriksen EF, Charles P, Melsen F, Mosekilde L, Risteli L, Risteli J. Serum markers of type I collagen formation and degradation in metabolic bone disease. Correlation to bone histomorphometry. I Bone Miner Res 1993; 8: 127-32.

10 Pera A, Bellando P, Caldera D, Ponti V, Astegiano M, Barletti C, et al. Colonoscopy in inflammatory bowel
disease: diagnostic accuracy and proposal of an endodisease: diagnostic accuracy and proposal of

11 Chong SKF, Blackshaw AJ, Boyle S, Williams CB, WalkerSmith JA. Histological diagnosis of chronic inflammatory bowel disease in childhood. Gut 1985; 26: 55-9.

12 Rutegard I, Ahsgren L, Stenling R, Nilsson T. A simple index for assessment of disease activity in patients with ulcerative colitis. Hepatogastroenterology 1990; 37 (suppl 2P): 110-2.

13 The Committee on Enzymes of the Scandinavian Society for Clinical Chemistry and Clinical Physiology. Recommended methods for the determination of four enzymes in blood. Scand 7 Clin Invest 1974; 33: 291-306.

14 Risteli J, Elomaa I, Niemi S, Novamo A, Risteli L Radioimmunoassay for the pyridoline cross-linked carboxyterminal telopeptide of type I collagen: a new carboxyterminal telopeptide of type I collagen: a new serum marker of bon

15 Melkko J, Niemi S, Risteli L, Risteli J. Radioimmunoassay of the carboxyterminal propeptide of human type I procollagen. Clin Chem 1990; 36: 1328-32.

$16 \mathrm{Kröger} \mathrm{H,} \mathrm{Laitinen} \mathrm{K}$. Bone mineral density measured by dual-energy X-ray absorptiometry in normal men. Eur $\mathcal{F}$ Clin Invest 1992; 22: 454-60.

17 Kröger H, Heikkinen J, Laitinen K, Kotaniemi A. Dualenergy X-ray absorptiometry in normal women: a crosssectional study of 717 Finnish volunteers. Osteoporosis Int 1992; 2: 135-40.

18 Välimäki MJ, Kärkkäinen $M$, Lamberg-Allardt C, Laitinen $\mathrm{K}$, Alhava E, Heikkinen J, et al. Exercise, smoking and $\mathrm{K}$, Alhava E, Heikkinen $\mathrm{J}$, et al. Exercise, smoking and calcium intake during adolescence and early adulthood as dete $230-5$.

19 Pietschmann P, Konflach P, Wolosczczuk W. Increased serum osteocalcin levels in patients with lactase deficiency. Am $\mathcal{F}$ Gastroenterol 1991; 86: 72-4.

20 Haukipuro K, Melkko J, Risteli L, Kairaluoma MI, Risteli J. Synthesis of type I collagen in healing wounds in humans. Ann Surg 1991; 213: 76-80.

21 Oikarinen A, Autio P, Kiistala U, Risteli L, Risteli J. A new method to measure type I and III collagen synthesis in human skin in vivo: demonstration of decreased collagen hynthesis after topical glucocorticoid treatment. $f$ Invest Dermatol 1992; 98: 220-5.

22 Jensen IT, Olesen HP Risteli J, Lorenzen I. External thoracic duct-venous shunt in conscious pigs for long
term studies of connective tissue metabolites in lymph. term studies of connective tiss

23 Kjeldsen J, Junker P, Scaffalitzky de Muckadell OB. Evidence that collagen I turnover is increased in active Crohn's disease. Gastroenterology 1994; 106 (suppl): A712.

24 Bjarnason I, Li F, Buxton-Thomas M, Forgacs I, Moniz C, Macpherson A. Mechanism of osteoporosis in patients with inflammatory bowel disease. Gastroenterology 1994; 106 (suppl): A652.

25 Oikarinen A, Autio P, Vuori J, Väänänen K, Risteli L, Kiistala U, et al. Systemic glucocorticoid treatment decreases serum concentrations of carboxyterminal propeptide of type I procollagen and aminoterminal propeptide of type I procollagen and aminoterminal 126: $172-8$. 